\title{
Insulin-Like Growth Factor Family and Combined Antisense Approach in Therapy of Lung Carcinoma
}

\author{
Jasminka Pavelić, ${ }^{1}$ Ljubomir Pavelić, ${ }^{2}$ Jerolim Karadža, ${ }^{2}$ Šimun Križanac, ${ }^{1}$ Josip Unešić, $^{3}$ Šime Spaventi, $^{4}$ \\ and Krešimir Pavelić ${ }^{1}$ \\ ${ }^{1}$ Division of Molecular Medicine, Ruder Bošković Institute, Zagreb, Croatia \\ ${ }^{2}$ Clinical Hospital of Pulmonary Diseases “Jordanovac," Zagreb, Croatia \\ ${ }^{3}$ Clinical Hospital "Rebro," Zagreb, Croatia \\ ${ }^{4}$ Croatian Academy of Sciences and Arts, Zagreb, Croatia
}

Accepted March 11, 2002

\begin{abstract}
Background: Perturbation in a level of any peptide from insulin-like growth factor (IGF) family (ligands, receptors, and binding proteins) seems to be implicated in lung cancer formation; IGF ligands and IGF-I receptor through their mitogenic and anti-apoptotic action, and the mannose 6-phosphate/insulin-like growth factor II receptor (M6-P/IGF-IIR) possibly as a tumor suppressor.

Materials and Methods: To determine the identity, role, and mutual relationship of IGFs in lung cancer growth and maintenance, we examined IGF's gene (by RT-PCR) and protein (by immunohistochemistry) expression in $69 \mathrm{hu}-$ man lung carcinoma tissues. We also examined IGF-I receptor numbers (Scatchard analysis) and IGF-II production and release (by Western blot) in IGF-II/IGF-IR mRNA positive and negative lung carcinomas. Finally, the potential role of IGF-IR and IGF-II as growth promoting factors in lung cancer was studied using antisense oligodeoxynucleotides that specifically inhibit IGF-IR and IGF-II mRNA. Results: Thirty-two tumors were positive for IGF-I, 39 for IGF-II, 48 for IGF-IR, and 35 for IGFBP-4 mRNA. Seventeen tumors were concomitantly positive for all four IGFs, whereas 34 were positive for IGF-II, IGF-IR, and IGFBP-4
\end{abstract}

mRNA. An elevated amount of IGF-II peptide was secreted into the growth medium of cell cultures established from five different IGF-II/IGF-IR mRNA positive lung cancer tissues. The cells also expressed elevated numbers of IGF-IR. Nine IGF-II-negative and 19 IGF-II-positive lung cancers of different stages were selected, and M6-P/ IGF-II receptor was determined immunohistochemically. Most of the IGF-II-negative tumors were strongly positive for M6-P/IGF-IIR. IGF-II-positive tumors were mostly negative for M6-P/IGF-II receptors. Antisense oligodeoxynucleotides to IGF-II significantly inhibited, by $25-60 \%$, the in vitro growth of all six lung cancer cell lines. However, the best results (growth inhibition of up to $80 \%$ ) were achieved with concomitant antisense treatment (to IGF-IR and IGF-II).

Conclusion: Our data suggest that lung cancer cells produce IGF-IR and IGF-II, which in turn stimulates their proliferation by autocrine mechanism. Cancer cell proliferation can be abrogated or alleviated by blocking the mRNA activity of these genes indicating that an antisense approach may represent an effective and practical cancer gene therapy strategy.

\section{Introduction}

Numerous growth factors and receptors have been shown to be involved in the development and maintenance of transformed phenotype of lung cancer cell lines and in vivo growing lung tumors, including neuroendocrine small cell lung carcinoma. These growth factors are peptides with either autocrine or paracrine effects. Essential is the role of peptides from insulin-like growth factor (IGF) family of ligands, receptors, and binding proteins, which form highly regulated networks of interactions (1). They are insulinlike growth factors (IGF) -I and -II, whose growth promoting action is mediated mostly by IGF-I receptor

Address correspondence and reprint requests to: Professor Jasminka Pavelić, PhD, Ruder Bošković Institute, Division of Molecular Medicine, Bijenička cesta 54, P.O. Box 180, HR-10002 Zagreb, Croatia. Phone: 385-1-4680094; fax 385-1-4561010; e-mail: jpavelic@rudjer.irb.hr.
(IGF-IR) and at least six IGF binding proteins (IGFBP) that regulate IGF-I and IGF-II bioavailability. In turn IGFBP activity is regulated by IGFBP proteases among other factors.

IGF-I and IGF-II and the IGF-I receptor are critically important for normal growth and development of the organism. IGF-I receptors mediates IGF-I and IGF-II action on prenatal growth and IGF-I action on postnatal growth. Mice depleted of IGF-I receptors die at birth as a result of poor muscular development. However, IGF ligands are also implicated in numerous pathologic states, including malignancy, where they serve as endocrine, autocrine, and paracrine stimulators of mitogenesis, survival, and cellular transformation $(2,3)$. These actions are mediated through the IGF-I receptor. They also act synergistically with other growth factors and steroids and antagonize the effect of antiproliferative molecules on cancer growth. 
IGFBP have opposing action (to IGF ligands/ receptors) mediated either by IGF binding or by direct inhibitory effects on target cells, however, only when not under the strong activity of IGFBP proteases that enhance IGFs bioavailability by cleaving IGFBPs (4).

IGF-II is a commonly expressed growth factor in many tumors and may enhance tumor growth acting via the over-expressed IGF-I receptor. The IGF-II gene is transcribed from four different promoters, and promoters $\mathrm{P} 3$ and $\mathrm{P} 4$ have been implicated in most tumors studied (5). IGF-II protein could be expressed at various molecular weights; the most active form, with regard to binding to IGF-I receptors, is $7.5 \mathrm{kDa}(6)$. Larger forms lack posttranslational modification and are implicated in tumor-associated hypoglycemia. The secretion of IGF-II by tumors and tumor-derived cell lines suggest that it may act as autocrine regulator of cell proliferation. The frequent expression of $I G F-I I$ gene in human and animal tumors additionally supports the belief that IGF-II plays an important role in tumor development. Its over-expression increases the probability of malignant transformation, and the mammary gland is at particularly high risk of tumor development (7).

The IGF-I receptor has been identified as a potential control point for transformed cells (8). It is also a well-defined target of IGF-II-modulated cell growth, both normal and neoplastic (9). In addition to being stimulated by IGF-II, IGF-I receptors may be overexpressed in some tumors, due to the mutations in tumor suppressor gene products such as p53 and WT-1 or growth factors such as $\beta F G F$ and PDGF. Overexpression of receptors transforms cells to a phenotype of the anchorage-independent growth factor (10).

Contrary to IGF-IR, the mannose 6-phosphate/ insulin-like growth factor II receptor (M6-P/IGFIIR) mediates the activation of the growth inhibitor (TGF- $\beta 1$ ) and clearance of IGF-II. Binding of IGF-II to IGF-IIR results in degradation of the ligand, making it unable to activate IGF-IR. M6-P/IGF-IIR has also been shown to be mutated in a number of human tumors including squamous cell carcinoma of the lung (11). Both of these findings identify M6-P/IGF-IIR as a tumor suppressor.

The role of IGF-II in transformation depends on tumor type (5). In this respect, in human lung cancer cell lines the IGF-II gene is more widely expressed than the IGF-I gene (12). There may be also a close association between IGF-II and IGFBP-2 gene expression, such that, when there is production of IGF-II, IGFBP-2 is the principal BP $(12,13)$. Takanami's findings suggest that IGF-I and -II play an important role in tumor progression and that IGF-II is a useful prognostic marker for pulmonary adenocarcinomas (14-16). The idea that the IGF-II/IGF-IR autocrine loop is a common growth mechanism in epithelial cancer is drawing more and more attention $(11,17)$. Therefore, these tumors would be excellent candidates for therapeutic strategies aimed at interference with this pathway. Disruption of the IGF-II pathway can be accomplished through binding of growth factors, blockage of receptors, or inhibition of secondary targets. Here we examine the gene expression of IGF ligands and receptors in different lung cancers. Combined treatment with antisense oligodeoxynucleotides to IGF-IR and IGF-II significantly inhibited the growth of six lung cancer cell lines.

\section{Materials and Methods}

Tissue Specimens

A total of 69 lung carcinomas (38 squamous cell carcinomas, 20 adenocarcinomas, 6 adenosquamous cell carcinomas, and 5 large cell carcinomas; Table 1) obtained from human tumor bank (18) were analyzed. These were obtained from patients treated surgically (46 males, aged 38-77 years, mean 60 years, and 23 females, aged 47-73, mean 60 years). The tissues were snap frozen in liquid nitrogen shortly after surgical removal, brought immediately to the laboratory, and stored at $-80^{\circ} \mathrm{C}$. A part of each frozen tumor sample was also embedded in paraffin. Sections of each paraffin block were stained with hematoxylin and eosin to confirm the exact tissue analyzed. Frozen sections $(4 \mu \mathrm{m})$ adjacent to those used for histopathologic analysis were used for RNA analysis and establishment of primary cell cultures. All persons gave their informed consent prior to inclusion in the study. Local ethics committees approved the study.

\section{RNA Extraction and Reverse Transcription PCR}

For RNA extraction, tissue samples were homogenized in $1 \mathrm{ml}$ of solution containing $4 \mathrm{M}$ guanidinium thyocianate, $25 \mathrm{mM}$ sodium citrate, $\mathrm{pH}$ 7.0, 5g/l sarkosyl and $100 \mathrm{mM}$ 2-mercaptoethanol (19). Reverse transcription $\left(42^{\circ} \mathrm{C}\right.$ for $\left.1 \mathrm{hr}\right)$ procedure for all IGF RNAs was performed exactly as it is described in Pavelić et al. $(20,21)$. The cDNA fragments were of the following size: IGF-I 397 bp, IGF-II 541 bp, IGF-IR 720 bp, IGFBP-4 180 bp, $\beta$-actin 317 bp (Fig. 1).

\section{Cultivation of Lung Cancer Cells}

Tumor tissue, without necroses, was cut into small pieces and pressed through a nylon sieve. Cells (approximately $3-6 \times 10^{5}$ ) were put into T-75 flasks with RPMI 1640 medium supplemented with $15 \%$ fetal calf serum, 1\% calf serum, 1\% glutamine, and 20 mM HEPES. Tumor cell cultures, obtained from samples indicated in Table 1 in bold, were maintained as monolayers.

Cell number was determined by the MTT dye reduction assay. The cells (obtained from samples number 3, 32, 38, 48, 56, and 62; Table 1) seeded in 96-well plates $\left(3 \times 10^{4} /\right.$ well $)$, were grown overnight at $37^{\circ} \mathrm{C}$ and $5 \% \mathrm{CO}_{2}$. For an additional $72 \mathrm{hr}$, the cells were incubated in medium containing $0.1 \%$ bovine serum albumin, $5 \mu \mathrm{g} / \mathrm{ml}$ transferrin, $5 \mathrm{ng} / \mathrm{ml}$ selenic acid, and antibiotics with or without addition of antisense or sense oligodeoxynucleotides. 


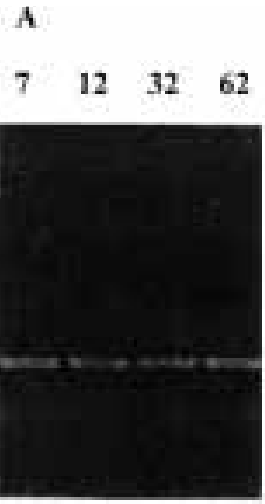

B

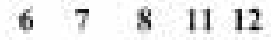

$397 \mathrm{bp}$

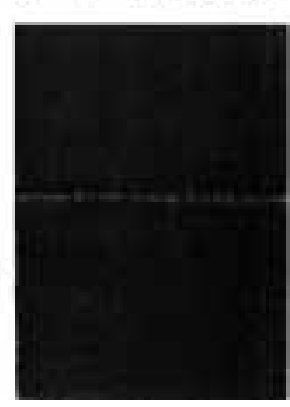

541 bp

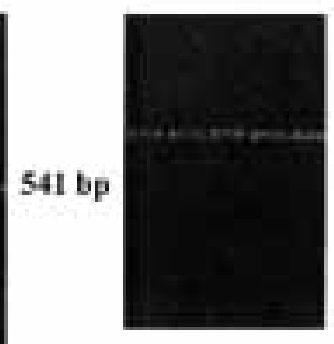

$720 \mathrm{bp}$

Fig. 1. IGF-I (A), IGF-II (B), and IGF receptor type I (C) mRNA (RT-PCR) in some of the specimens of lung cancer tissue. Numbers above the lines indicate the corresponding tumor sample (patient) listed in Table 1.
Absorbance was measured at $570 \mathrm{~nm}$ with ELISA plate reader (Labsystems, Multiscan $\mathrm{MS}$ ). Data are expressed as the percentage of increase or decrease in cell growth compared to untreated control cells.
Immunohistochemistry

Immunohistochemical tests were performed on formalin-fixed, paraffin-embedded tissue using avidin-biotin-peroxidase method. Sections were cut

Table 1. Pathohistologic classification, TNM stage, and IGF's RNA positivity in lung cancer tissues

\begin{tabular}{|c|c|c|c|c|c|c|c|c|}
\hline No & $\begin{array}{c}\text { Patient } \\
\text { Age }\end{array}$ & $\begin{array}{l}\text { Patient } \\
\text { Sex }\end{array}$ & $\begin{array}{l}\text { Tumor } \\
\text { Subtype }\end{array}$ & $\begin{array}{l}\text { TNM } \\
\text { Stage }\end{array}$ & IGF-I & IGF-II & IGF-IR & IGFBP-4 \\
\hline 1 & 49 & M & AC & I & + & - & - & - \\
\hline 2 & 56 & M & $\mathrm{AC}$ & I & + & - & - & - \\
\hline 3 & 59 & $\mathbf{M}$ & AC & I & - & + & + & + \\
\hline 4 & 57 & M & AC & II & - & + & + & + \\
\hline 5 & 63 & $\mathrm{~F}$ & AC & II & - & - & - & - \\
\hline 6 & 51 & $\mathrm{~F}$ & $\mathrm{AC}$ & II & - & + & + & + \\
\hline 7 & 50 & $\mathbf{M}$ & AC & II & + & + & + & + \\
\hline 8 & 61 & M & AC & II & - & + & + & + \\
\hline 9 & 71 & $\mathrm{~F}$ & AC & II & - & - & - & - \\
\hline 10 & 65 & M & AC & II & - & - & - & - \\
\hline 11 & 54 & $\mathrm{~F}$ & $\mathrm{AC}$ & II & + & + & + & + \\
\hline 12 & 58 & M & AC & II & + & + & + & + \\
\hline 13 & 74 & M & AC & II & - & + & + & + \\
\hline 14 & 65 & M & $\mathrm{AC}$ & IIIa & + & + & + & + \\
\hline 15 & 70 & $\mathrm{~F}$ & $\mathrm{AC}$ & IIIa & - & + & + & + \\
\hline 16 & 62 & M & $\mathrm{AC}$ & IIIa & - & + & + & + \\
\hline 17 & 52 & M & $\mathrm{AC}$ & IIIa & + & - & + & - \\
\hline 18 & 52 & M & $\mathrm{AC}$ & IIIa & - & - & + & - \\
\hline 19 & 68 & $\mathrm{~F}$ & $\mathrm{AC}$ & IIIa & + & - & + & - \\
\hline 20 & 66 & $\mathrm{~F}$ & $\mathrm{AC}$ & IIIa & + & - & + & - \\
\hline 21 & 77 & $\mathbf{M}$ & AS & I & + & - & + & - \\
\hline 22 & 63 & $\mathbf{M}$ & AS & I & - & - & - & - \\
\hline 23 & 65 & $\mathbf{M}$ & AS & I & - & - & - & - \\
\hline 24 & 59 & $\mathbf{M}$ & AS & I & + & + & + & + \\
\hline 25 & 67 & $\mathbf{M}$ & AS & II & + & + & + & + \\
\hline 26 & 66 & $\mathbf{M}$ & AS & II & + & - & - & - \\
\hline
\end{tabular}


Table 1. (Continued)

\begin{tabular}{|c|c|c|c|c|c|c|c|c|}
\hline No & $\begin{array}{c}\text { Patient } \\
\text { Age }\end{array}$ & $\begin{array}{l}\text { Patient } \\
\text { Sex }\end{array}$ & $\begin{array}{l}\text { Tumor } \\
\text { Subtype }\end{array}$ & $\begin{array}{l}\text { TNM } \\
\text { Stage }\end{array}$ & IGF-I & IGF-II & IGF-IR & IGFBP-4 \\
\hline 27 & 61 & F & LCA & I & + & - & + & - \\
\hline 28 & 57 & F & LCA & I & - & - & - & - \\
\hline 29 & 68 & $\mathbf{M}$ & LCA & IIIa & - & + & + & - \\
\hline 30 & 60 & M & LCA & IIIa & - & + & + & - \\
\hline 31 & 65 & $\mathbf{M}$ & LCA & IIIa & + & - & - & - \\
\hline 32 & 65 & $\mathbf{M}$ & SCC & I & + & + & + & + \\
\hline 33 & 41 & $\mathbf{M}$ & SCC & I & + & - & - & - \\
\hline 34 & 57 & F & SCC & I & + & + & + & + \\
\hline 35 & 73 & F & SCC & I & + & + & + & + \\
\hline 36 & 57 & F & SCC & I & + & - & - & - \\
\hline 37 & 73 & $\mathbf{M}$ & SCC & I & - & - & + & + \\
\hline 38 & 38 & $\mathbf{M}$ & SCC & I & - & + & + & + \\
\hline 39 & 44 & $\mathbf{M}$ & SCC & I & - & + & + & + \\
\hline 40 & 57 & M & SCC & I & + & - & - & - \\
\hline 41 & 50 & $\mathbf{M}$ & SCC & I & - & - & + & - \\
\hline 42 & 60 & F & SCC & I & - & + & + & + \\
\hline 43 & 51 & $\mathbf{M}$ & SCC & I & - & - & - & - \\
\hline 44 & 53 & F & SCC & I & + & + & + & + \\
\hline 45 & 51 & M & SCC & II & + & + & + & + \\
\hline 46 & 47 & F & SCC & II & + & - & - & - \\
\hline 47 & 59 & F & SCC & II & + & + & + & + \\
\hline 48 & 77 & $\mathbf{M}$ & SCC & II & - & + & + & - \\
\hline 49 & 47 & $\mathbf{M}$ & SCC & II & - & - & - & - \\
\hline 50 & 59 & M & SCC & II & - & - & - & - \\
\hline 51 & 63 & M & SCC & II & + & - & - & - \\
\hline 52 & 62 & $\mathbf{M}$ & SCC & II & - & + & + & + \\
\hline 53 & 60 & F & SCC & II & - & + & + & + \\
\hline 54 & 58 & F & SCC & II & + & + & + & - \\
\hline 55 & 73 & F & SCC & II & + & + & + & + \\
\hline 56 & 49 & M & SCC & II & - & + & + & - \\
\hline 57 & 65 & $\mathbf{M}$ & SCC & II & - & - & - & - \\
\hline 58 & 64 & $\mathbf{M}$ & SCC & II & + & + & + & + \\
\hline 59 & 48 & $\mathbf{M}$ & SCC & IIIa & - & + & + & + \\
\hline 60 & 55 & F & SCC & IIIa & - & + & + & + \\
\hline 61 & 64 & F & SCC & IIIa & - & + & + & + \\
\hline 62 & 77 & $\mathbf{M}$ & SCC & IIIa & + & + & + & + \\
\hline 63 & 49 & $\mathbf{M}$ & SCC & IIIa & - & + & + & + \\
\hline 64 & 59 & $\mathbf{M}$ & SCC & IIIa & + & + & + & + \\
\hline 65 & 70 & F & SCC & IIIa & + & + & + & + \\
\hline 66 & 71 & M & SCC & IIIa & - & + & + & + \\
\hline 67 & 76 & $\mathbf{M}$ & SCC & IIIa & - & - & + & - \\
\hline 68 & 53 & $\mathbf{M}$ & SCC & IIIa & - & - & - & - \\
\hline 69 & 68 & F & SCC & IIIa & - & - & - & - \\
\hline
\end{tabular}

Abbreviations: AC, adenocarcinoma; AS, adenosquamous cell carcinoma; LSC, large cell carcinoma; SCC, squamous cell carcinoma; M, male; F, female; (bold) = tumor cell cultures maintained in monolayers. 
Table 2. Number of IGF mRNA positive lung cancer tissues

\begin{tabular}{|c|c|c|c|c|c|}
\hline & & +IGF-IR & +IGFBP-4 & +IGF-IR + IGFBP-4 & +IGF-IR + IGFBP-4 + IGF-II \\
\hline IGF-I & $\begin{array}{c}32 \\
46.4 \%\end{array}$ & $\begin{array}{c}23 \\
33.3 \%\end{array}$ & $\begin{array}{c}17 \\
24.6 \%\end{array}$ & $\begin{array}{c}17 \\
24.6 \%\end{array}$ & $\begin{array}{c}17 \\
24.6 \%\end{array}$ \\
\hline IGF-II & $\begin{array}{c}39 \\
56.5 \%\end{array}$ & $\begin{array}{c}39 \\
56.5 \%\end{array}$ & $\begin{array}{c}34 \\
49.2 \%\end{array}$ & $\begin{array}{c}34 \\
49.2 \%\end{array}$ & - \\
\hline IGF-IR & $\begin{array}{c}48 \\
69.6 \%\end{array}$ & - & $\begin{array}{c}35 \\
50.7 \%\end{array}$ & - & - \\
\hline IGFBP-4 & $\begin{array}{c}35 \\
50.7 \%\end{array}$ & $\begin{array}{c}35 \\
50.7 \%\end{array}$ & - & - & - \\
\hline None IGF & $\begin{array}{c}12 \\
17.4 \%\end{array}$ & - & - & - & - \\
\hline Total & $\begin{array}{c}69 \\
100 \%\end{array}$ & - & - & - & - \\
\hline
\end{tabular}

at $4 \mu \mathrm{m}$, deparaffinized, and rehydrated. After blocking endogenous peroxidase activity by $3 \%$ hydrogen peroxide, the slides were subjected to a heat-induced epitope retrieval technique in $10 \mathrm{mM}$ citrate buffer ( $\mathrm{pH}$ 6.0) in an $850 \mathrm{~W}$ microwave for 10 min. Anti-IGF-II (Upstate Biotechnologies, Lake Placid, NY, USA) is an mouse monoclonal antibody, diluted 1:50, and incubated for 15-18 hr. Anti-IGF-IR (Santa Cruz Biotechnologies, Santa Cruz, CA, USA) is a rabbit polyclonal antibody, diluted 1:100, and incubated also for 15-18 hr. Anti M6-P/IGF-IIR rabbit polyclonal antibody was generous gift from Zeneco (URL: http://www.geneimprint.com). Detection was achieved using the DAKO (Carpinteria, CA, USA) LSAB 2 kit, according to manufacturer's instructions. Negative controls were stained by substitution of the primary antibodies with nonimmune mouse or rabbit immunoglobulins at same concentrations as the corresponding antibodies. Appropriate positive controls (normal thyroid gland for IGF-IR, Wilms' tumor for IGF-II and normal colon for M6-P/IGF-IIR) were stained positively. The tumor cells showed, in both cases, strong diffuse cytoplasmic immunopositivity for IGF-II and M6P/IGF-IIR, and cytoplasmic and focal membranous reactivity for IGF-IR (Table 2 ).

IGF-II Studies in Cell Growth Medium

Tumor cell cultures, established from samples number 7, 62 (IGF-II/IGF-IR mRNA positive), and 33 (IGFII/IGF-IR mRNA negative, control cells) (Table 1) were grown in serum-containing medium in $1 \times 24$ well culture plates. Immunoenzymatic detection of IGF-II was done in conditioned medium collected on days 5 and 25 of in vitro cell growth by using a mouse monoclonal antibody directed against native rat IGFII and a secondary goat anti-mouse IgG serum conjugated to horseradish peroxidase. Semiquantitative measurements of immunoreactive IGF-II were performed by chemiluminescence on serial dilutions of conditioned media spotted on BA85 nitrocellulose filters. Signals were analyzed using Pharmacia (Newark, NJ, USA) LKB system. Values for IGF-II were interpolated from standard curves using serial dilutions of human IGF-II. IGF-II concentrations are expressed as $\mathrm{ng} / 2 \times 10^{6}$ cells (Table 3 ).

Table 3. The level of IGF-II peptide in cell growth medium and number of IGF-I receptors on cultured lung cancer cells

\begin{tabular}{|c|c|c|c|c|}
\hline \multirow[b]{2}{*}{ Cell Type } & \multicolumn{2}{|c|}{ IGF-II $\left(\mathrm{ng} / 2 \times 10^{6} \text { Cells }\right)^{*}$} & \multicolumn{2}{|c|}{ IGF-IR $B \max \left(\mathrm{fmol} / 2 \times 10^{6} \text { Cells }\right)^{*}$} \\
\hline & Day 5 & Day 25 & Day 5 & Day 25 \\
\hline AC, case \# 7 & $323.3 \pm 37.9$ & $34.7 \pm 11.6$ & $210.7 \pm 18.8$ & $24.3 \pm 17.2$ \\
\hline SCC, case \# 62 & $231.3 \pm 33.6$ & $214.7 \pm 19.6$ & $180.0 \pm 26.9$ & $66.0 \pm 16.5$ \\
\hline SCC, case \# $33^{+}$ & $7.0 \pm 2.0$ & $4.0 \pm 3.6$ & $60.0 \pm 18.7$ & $13.7 \pm 2.0$ \\
\hline
\end{tabular}

\footnotetext{
*Values are the mean \pm SD of three independent experiments (in all cases statistically different from control values obtained with cells \#33). ${ }^{+}$IGF-II/IGF-IR mRNA negative cells.
} 


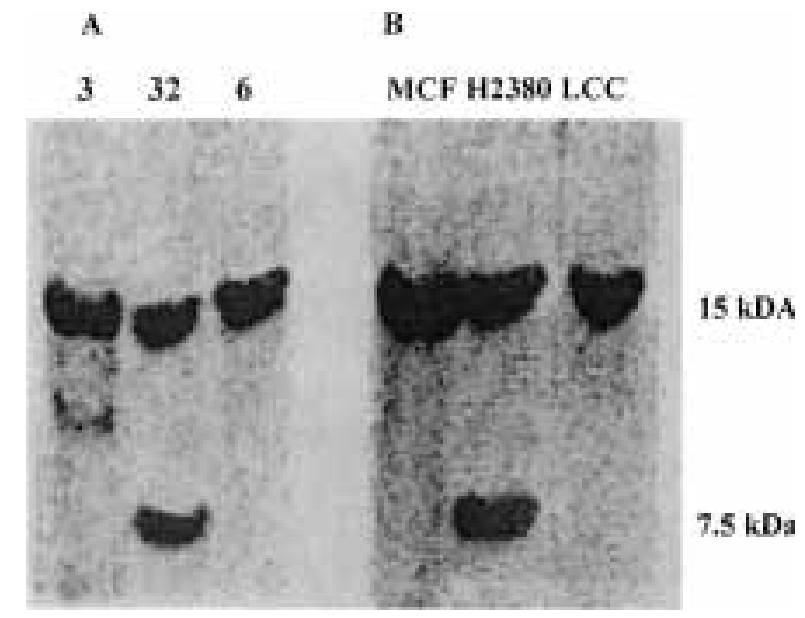

Fig. 2. Western blot analysis of IGF-II secreted into the growth medium (day 10) of (A) cell cultures established from three lung cancer tissues and (B) in three established cell lines (two breast adenocarcinomas, MCF-7 and H2380, and primary lung carcinoid cell line, LCC). Numbers above the lines in A indicate the corresponding tumor sample (patient) listed in Table 1.

\section{Western Blot}

IGF-II was analyzed by Western immunoblot using specific anti-IGF-II monoclonal antibody (Amano Pharmaceutical, Japan) (Fig. 2). The cell growth media collected on day 10 of cell growth (cultures established from samples 3, 32, and 56; Table 1) was electrophoresed on $16 \%$ SDS polyacrylamide gel under nonreducing conditions. The fractionated proteins were electroblotted on the nitro-cellulose sheet, blocked with $5 \%$ w/v skim milk, and then immunoblotted with anti-IGF-II monoclonal antibody for $16 \mathrm{hr}$. After washing, the sheet was incubated with anti-mouse IgG. IGF-II anti-IGF-II antibody complexes were detected with enhanced chemiluminiscence system (22).

\section{IGF-I Receptor Assay}

IGF-I receptor detection was done on the cell cultures obtained from samples 7, 62, and 33 (Table 1). Cell receptor number was estimated by whole cell binding assay/Scatchard analysis (23). The cells were incubated, for $18 \mathrm{hr}$, with ${ }^{125}$ I-labeled IGF-I and with or without increasing concentrations of unlabeled IGF-I. Finally, the cells were lysed in PBS containing Triton X-100 and $10 \%$ glycerol, and the radioactivity was counted in gamma counter (Pharmacia). Nonspecific binding represented about $5 \%$ of total ${ }^{125}$ I-IGF-I binding.

\section{Antisense and Sense Oligodeoxynucleotides}

All oligodeoxynucleotides were synthesized as mixed phosphorothiodates. The IGF-IR: antisense 5'TCCTCCGGAGCCAGACTT 3' (complementary to codons 21-29 of the signal sequence of the human
IGF-IR) and sense 5'AAGTCTGGCTCGGAGGA 3'; IFG-II: antisense 5'TTCCCCATTGGGATTCCCAT 3' (corresponding to the IGF-II mRNA initiation site) and sense 5'ATGGGAATCCCAATGGGGAA 3'.

\section{Statistical Analysis}

Statistically significant differences were determined by using Student $t$-test. The level of significance was set at $p<0.01$.

\section{Discussion}

In our study, $82.6 \%$ of lung cancers expressed mRNA for one of the IGF members. The majority of tumors expressed IGF-II, IGF-IR, and IGFBP-4, indicating their important role in lung carcinogenesis. The growth of lung cancers that produce IGF-II was regulated by autocrine IGF-II/IGF-IR-mediated stimulation, as suggested by the observation that abrogation of receptor and/or ligand function by antisense oligodeoxynucleotides inhibited lung cancer cell proliferation in vitro. IGF-II-/IGF-IR-positive tumors, mostly those of advanced stage, fail to express M6-P/IGF-II receptors. Therefore, our results clearly demonstrate the importance of IGF-II, IGFIR, and possibly M6-P/IGF-IIR in the pathogenesis of lung cancer (Table 4, Fig. 3).

Perturbation in a level of each IGF has been implicated in cancer formation in various cell types. Several studies have demonstrated an overexpression of IGF receptors and other members of the family by tumor cells, for example, of thyroid, breast, and colon cancer, hepatoma, and endometrial carcinoma (24-26). There is little doubt that many neoplastic cells express IGFs and show growth enhancement in response to IGFs.

There are also findings showing that IGF-IR is an absolute requirement for the establishment and maintenance of transformed phenotype in some tumors (27). In concordance with this are also our recent data showing undoubtedly that IGF-IR is important for development and progression of human hemangiopericytomas $(20,21)$.

On the other hand, receptor function can be abrogated by utilizing monoclonal antibodies against receptors such as $\alpha$ IR3 (28), the polyanionic compound suramine (29), phosphorylation-defective analogs of the IGF-I ligand (28), or antisense oligodeoxynucleotides directed against the IGF-IR mRNA. A series of experiments based on antisense strategies against the IGF-IR (30-32) have unequivocally shown that a decrease in the number of IGF-IR causes a reversal of the transformed phenotype.

The role of IGF-IR and IGF-II in the proliferation of lung cancer cells remains poorly understood. However, IGF-II autocrine stimulation through IGF-IR found in some human tumors of epithelial origin $(33,34)$ implies the possibility of the same mechanism of action in lung cancer. The results 
Table 4. M6-P/IGF-IIR protein immunohistochemical test in IGF-II negative and IGF-II positive tumors

\begin{tabular}{|c|c|c|c|c|c|}
\hline Patient & $\begin{array}{l}\text { Tumor } \\
\text { Subtype }\end{array}$ & $\begin{array}{l}\text { TNM } \\
\text { Stage }\end{array}$ & IGF-IR* & $\begin{array}{l}\text { IGF-IR } \\
\text { mRNA* }\end{array}$ & $\begin{array}{c}\text { M6-P/ } \\
\text { IGF-IIR* }^{*+}\end{array}$ \\
\hline IGF-II & nagative & tumors & & & \\
\hline 1 & AC & I & 0 & - & +++ \\
\hline 2 & $\mathrm{AC}$ & I & 0 & - & ++ \\
\hline 5 & $\mathrm{AC}$ & II & 0 & - & ++ \\
\hline 9 & $\mathrm{AC}$ & II & 0 & - & +++ \\
\hline 10 & $\mathrm{AC}$ & II & 0 & - & + \\
\hline 31 & LCA & IIIa & 0 & - & +++ \\
\hline 67 & SCC & IIIa & ++ & + & ++ \\
\hline 68 & $\mathrm{SCC}$ & IIIa & 0 & - & +++ \\
\hline 69 & SCC & IIIa & 0 & - & +++ \\
\hline IGF-II & positive & tumors & & & \\
\hline 3 & $\mathrm{AC}$ & I & ++ & + & 0 \\
\hline 4 & $\mathrm{AC}$ & II & ++ & + & 0 \\
\hline 6 & $\mathrm{AC}$ & II & +++ & + & ++ \\
\hline 7 & $\mathrm{AC}$ & II & ++ & + & ++ \\
\hline 8 & $\mathrm{AC}$ & II & +++ & + & + \\
\hline 11 & AC & II & ++ & + & ++ \\
\hline 12 & $\mathrm{AC}$ & II & + & + & +++ \\
\hline 13 & AC & II & +++ & + & + \\
\hline 14 & $\mathrm{AC}$ & IIIa & +++ & + & + \\
\hline 15 & $\mathrm{AC}$ & IIIa & ++ & + & 0 \\
\hline 16 & $\mathrm{AC}$ & IIIa & +++ & + & 0 \\
\hline 30 & LCA & IIIa & +++ & + & + \\
\hline 39 & SCC & IIIa & +++ & + & 0 \\
\hline 60 & SCC & IIIa & +++ & + & 0 \\
\hline 61 & SCC & IIIa & ++ & + & ++ \\
\hline 62 & SCC & IIIa & +++ & + & + \\
\hline 63 & SCC & IIIa & ++ & + & + \\
\hline 64 & SCC & IIIa & +++ & + & 0 \\
\hline 65 & SCC & IIIa & +++ & + & + \\
\hline
\end{tabular}

*mRNA positive $(+)$ and negative $(-)$ samples

${ }^{{ }^{\dagger}} 0$ negative tumors;,,++++++ are weakly positive ++ , moderately positive, +++ strongly positive tumors.

presented in this paper prove all prerequisites that IGF's autocrine loop operates in lung cancer. These are concomitant expression of IGF-I, IGF-II, and IGF-IR mRNA and corresponding proteins, as well as tumor cell growth inhibition by IGF-II/IGF-IR antisense therapy. Recently, we showed a similar pattern of IGF's action in hemangiopericytomas. Almost all tumors expressed IGF-IR and/or IGF-II mRNA, and inhibition of ligand and receptor activity abrogated tumor proliferation in vitro $(20,21)$. These and the results of other authors suggest that IGF-II may function as important paracrine or autocrine growth factor for some tumors. In the lung carcinomas tested in this study, the autocrine IGF's action seems to be more plausible. This is corroborated especially by the fact that in vitro growing tumor cells, free of any non-lung cancer cells paracrine influence, express IGF-IR and secrete IGF-II. We strongly believe that some members of IGF family play a role in tumor self-incitement $(35,36)$.
Contrary to the oncogenic activity of IGF-I, IGFII, and IGF-IR, mannose 6-phosphate/IGF-II receptor functions in humans as a tumor suppressor; a significant part of this activity comes from the control of level of IGF-II. However, when mutated, most commonly by $\mathrm{LOH}$ in one allele and point mutation in another $(11,37)$, it loses its antioncogenic activity and neoplastic transformation, caused by IGF-II overaccumulation, may occur. Our results prove this notion: IGF-II-/IGF-IR-negative tumors express strongly M6-P/IGF-IIR protein irrespective of tumor subtype and stage. On a contrary note, IGF-II-/IGF-IR-positive tumors were mostly negative or slightly positive for type 2 receptors. They fail, almost completely, to express type 2 receptors as they progress to more aggressive TNM stage (stage III). Loss of receptor function and associated accumulation of IGF-II, which binds to and activates IGF-IR, increases intracellular growth signals and promotes cell proliferation. This indicates that 

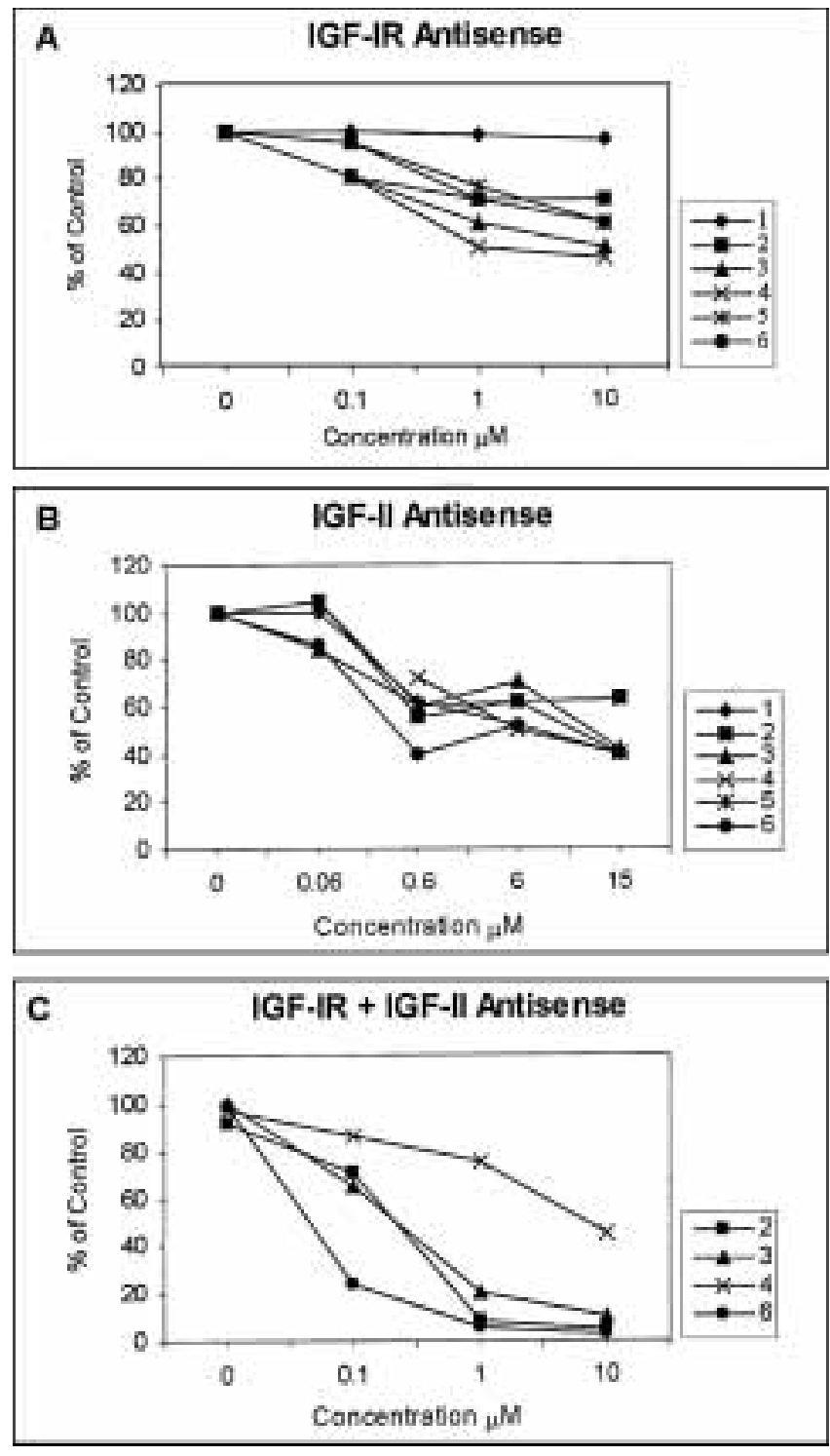

Fig. 3. Inhibition of lung cancer cell proliferation by an antisense oligodeoxynucleotides to IGF-IR mRNA (A) and IGF-II mRNA (B). Inhibition of lung cancer cell lines (line 2, sample 32; line 3, sample 38; line 4, sample 48; line 6, sample 62 from Table 1) by simultaneous treatment with antisense oligodeoxynucleotides to IGF-IR and IGF-II mRNAs (C). Each point represents the mean value of four replicate wells. The experiments were repeated three times.

IGF-IIR is also a part of IGF's autocrine loop, where operating as IGF-II antagonist, has tumor suppressor properties.

Considering the role of IGFs in neoplastic control, modulation of IGF physiology seems to be a reasonable choice in treatment of IGF-dependent cancers. There have been some successful attempts at IGF-targeted therapy of lung cancer or its brain metastasis by using either antisense approach, monoclonal antibodies, or suramin (38-41). Our in vitro results show that antisense therapy to IGF-II and
IGF-IR mRNA abrogates cell proliferation by preventing synthesis of specific proteins and disrupting intracellular signaling. However, despite the encouraging results from in vitro and in vivo studies using multiple cell lines, the limited clinical studies performed have been disappointing.

IGFBPs are small proteins that modulate IGF's biological effects by altering ligand-receptor interactions. Therefore, the concomitant expression of IGFBP-4 and IGF-I and IGF-II in 17 and 34 tumor samples, respectively, do not fit, at the moment, in the proposed autocrine IGF loop of action. However, the finding of gene expression at the mRNA level does not mean necessarily that the functional protein is synthesized; even if it is, there is the possibility that it is degraded rapidly by specific proteases. And finally, elevated expression of not only IGFBP-4, but also other binding proteins, together with elevated expression of IGF-I and IGF-II, was also observed by other authors, in both lung and other tumor models $(42,43)$. In a healthy organism, IGFBP-4 is produced locally by several cell types. It can also bind to the cell membrane, but the regulatory mechanisms of both actions are still unknown. Therefore, the question on the role of IGFBP-4 in carcinogenesis has to be elucidated further.

In conclusion, our results support the hypothesis that production of IGF-I, IGF-II, IGF-IR, and M6-P/IGF-IIR, different from that in normal tissue, influence lung cancer growth by autocrine mechanism. Targeting of IGF-I, IGF-II, and/or IGF-IR by "antisense" approach may represent an effective and practical cancer gene therapy strategy.

\section{Acknowledgments}

This work was supported by grants 00981103 and 00981104 from the Ministry of Science and Technology, Republic of Croatia.

\section{References}

1. Grimberg A, Cohen P. (2000) Role of insulin-like growth factors and their binding proteins in growth control and carcinogenesis. J. Cell Physiol. 183: 1-9.

2. Noll K, Wegmann BR, Havemann K, Jaques G. (1996) Insulin-like growth factors stimulate the release of insulin-like growth factor-binding protein-3 (IGFBP-3) and degradation of IGFBP-4 in nonsmall cell lung cancer cell lines. J. Clin. Endocrinol. Metab. 81: 2653-2662.

3. Wu XF, Yu H, Amos CI, Hong WK, Spitz MR. (2000) Joint effect of insulin-like growth factors and mutagen sensitivity in lung cancer risk. J. Natl. Cancer Inst, 92: 737-743.

4. Hwa V, Youngman O, Rosenfeld RG. (1999) The insulin-like growth factor binding protein (IGFBP) superfamily. Endocrine Rev. 20: 761-787.

5. Toretsky JA, Helman LJ. (1996) Involvement of IGF-II in human cancer. J. Endocrinol. 149: 367-372.

6. Kiess W, Yang Y, Kessler U, Hoeflich A. (1994) Insulin-like growth factor II (IGF-II) and the IGF-II mannose-6-phosphate receptor-the myth continues. Hormone Res. 41: 66-73.

7. Pravtcheva DD, Wise TL. (1998) Metastasizing mammary carcinomas in H19 enhancers IGF 2 transgenic mice. J. Exp. Zool. 281: 43-57. 
8. Resnicoff M, Sell C, Rubin M, et al. (1994) Rat glioblastoma cells expressing an antisense RNA to the insulin-like growth factor-1 (IGF-1) receptor are nontumorigenic and induce regression of wild-type tumors. Cancer Res. 54: 2218-2222.

9. Rubin R, Baserga R. (1995) Insulin-like growth factor-I receptor-its role in cell proliferation, apoptosis, and tumorigenicity. Lab. Invest. 73: 311-331.

10. Kaleko M, Rutter WJ, Miller AD. (1990) Overexpression of the human insulin-like growth factor I receptor promotes liganddependent neoplastic transformation. Mol. Cell Biol. 10: 464-473.

11. Kong FM, Anscher MS, Washington MK, Killian JK, Jirtle RL. (2000) M6P/IGF2R is mutated in squamous cell carcinoma of the lung. Oncogene 19: 1572-1578.

12. Reeve JG, Morgan J, Schwander J, Bleehen NM. (1993) Role for membrane and secreted insulin-like growth factor-binding protein-2 in the regulation of insulin-like growth factor action in lung tumors. Cancer Res. 53: 4680-4685.

13. Reeve JG, Brinkman A, Hughes S, Mitchell J, Schwander J, Bleehen NM. (1992) Expression of insulin-like growth factor (IGF) and IGF-binding protein genes in human lung tumor cell lines. J. Natl. Cancer Inst. 84: 628-634.

14. Takanami I, Imamua T, Hashizume T, et al. (1996) Expression of PDGF, IGF-II, BFGF and TGF- $\beta$ - 1 in pulmonary adenocarcinoma. Pathol. Res. Practice 192: 1113-1120.

15. Takanami I, Imamua T, Hashizume T, et al. (1996) Insulin-like growth factor-II as a prognostic factor in pulmonary adenocarcinoma. J. Surg. Oncol. 61: 205-208.

16. Takanami I, Tanaka F, Hashizume T, Kodaira S. (1997) Insulin-like growth factor IGF-I and IGF-II protein expression in pulmonary adenocarcinoma-an immunohistochemical study. Oncology Rep. 4: 493-496.

17. Quinn KA, Treston AM, Unsworth EJ, et al. (1996) Insulinlike growth factor expression in human cancer cell lines. J. Biol. Chem. 271: 11477-11483.

18. Spaventi R, Pečur L, Pavelić K, Pavelić ZP, Spaventi Š, Stambrook PJ. (1993) Human tumor bank in Croatia: a possible model for a small bank as a part of the future European tumor bank network. Eur. J. Cancer 30A: 419.

19. Gall-Trošelj K, Kušić B, Pećina-Šlaus N, Pavelić K, Pavelić J. (1995) Nested polymerase chain reaction for detection of hepatitis C virus RNA in blood derivatives. Eur. J. Clin. Chem. Clin. Biochem. 33: 733-736.

20. Pavelić K, Spaventi Š, Glunčić V, et al. (1999) The expression and role of insulin-like growth factor II in malignant hemangiopericytomas. J. Mol. Med. 77: 865-869.

21. Pavelić K, Pavelić ZP, Cabrijan T, Karner I, Samaržija M, Stambrook PJ. (1999) Insulin-like growth factor family in malignant hemangiopericytomas: the expression and role of insulin-like growth factor I receptor. J. Pathol. 188: 69-75.

22. Enjoh T, Hizuka N, Perdue JF, et al. (1993) Characterization of new monoclonal antibodies to human insulin-like growth factor II and their application in Western immunoblot analysis. J. Clin. Endocrinol. Metab. 77: 510-517.

23. Zarrilli R, Romano M, Pignata S, Casola S, Bruni CB, Acquaviva AM. (1996) Constitutive insulin-like growth factor-II expression interferes with the enterocyte-like differentiation of CaCo-2 cells. J. Biol. Chem. 27: 8108-8114.

24. MacDonald RG, Schaffer BS, Kang IJ, Hong S, Kim EJ, Park JH. (1999) Growth inhibition and differentiation of the human colon carcinoma cell line, Caco-2, by constitutive expression of insulin-like growth binding protein-3. J. Gastroenterol. Hepatol. 14: $72-78$.

25. Freier S, Weiss O, Eran M, et al. (1999) Expression of the insulin-like growth factors and their receptors in adenocarcinoma of the colon. Gut 44: 704-708.
26. Parisot JP, Hu XF, DeLuise M, Zalcberg JR. (1999) Altered expression of the IGF-I receptor in a tamoxifen-resistant human breast cancer cell line. Br. J. Cancer 79: 693-700.

27. Werner H, LeRoith D. (1995) Insulin-like growth factor I receptor: structure, signal transduction and function. Diabetes Review 3: 28-37.

28. McCaulay VM. (1992) Insulin-like growth factors and cancer. Br. J. Cancer 65: 311-320.

29. Pollak M, Richard M. (1990) Suramin blockade in insulinlike growth factor I stimulated proliferation of human osteosarcoma cells. J. Natl. Cancer Inst. 82: 1349-1352.

30. Arteaga CL. (1992) Interference of the IGF system as a strategy to inhibit breast cancer growth. Breast Cancer Res. Treat. 22: 101-106.

31. Trojan J, Blossey BK, Johnson TR, et al. (1992) Loss of tumorigenicity of rat glioblastoma directed by episome-based antisense cDNA transcription of insulin-like growth factor I. Proc. Natl. Acad. Sci. U.S.A. 89: 4874-4878.

32. Shapiro DN, Jones BG, Shapiro LH, Dias P, Houghton PJ. (1994) Antisense-mediated reduction in insulin-like growth factor I receptor expression suppresses the malignant phenotype of a human alveolar rhabdomyosarcoma. J. Clin. Invest. 94: 1235-1242.

33. Lamonerie T, Lavialle C, Haddada H, Brison O. (1995) IGF-II autocrine stimulation in tumorigenic clones of a human colon-carcinoma cell line. Int. J. Cancer 61: 587-592.

34. Guo YS, Jin GF, Townsend CM, et al. (1995) Insulin-like growth factor II expression in carcinoma in colon cell lines: implications for autocrine action. J. Am. Coll. Surg. 181: 145-154.

35. Pavelić K, Vrbanec D, Marušić S, Levanat S, Čabrijan T. (1986) Autocrine tumour growth regulation by somatomedin C: an in vitro model. J. Endocrinol. 109: 233-238.

36. Bajzer Ž, Pavelić K, Vuk-Pavlović S. (1984) Growth selfincitement in murine melanoma B16, a phenomenological model. Science 225: 930-932.

37. Rey JM, Theillet C, Brouillet JP, Rochefort H. (2000) Stable amino-acid sequence of the mannose-6-phosphate/ionsulin-like growth-factor-II receptor in ovarian carcinomas with loss of heterozygosity in breast-cancer cell lines. Int. J. Cancer 85: 466473.

38. Lee CT, Wu S, Gabrilovich D, Chen HL, et al. (1996) Antitumor effects of an adenovirus expressing antisense insulinlike growth factor I receptor on human lung cancer cell lines. Cancer Res. 56: 3038-3041.

39. Hwang CC, Fang K, Li L, Shih SH. (1995) Insulin-like growth factor-I is an autocrine regulator for the brain metastatic variant of a human non-small cell lung cell line. Cancer Lett. 94: 157-163.

40. Miglietta L, Barreca A, Repetto L, Costantini M, Rosso R, Boccardo F.(1993) Suramin and serum insulin-like growth factor levels in metastatic cancer patients. Anticancer Res. 13: 2473-2476.

41. Zia F, Jacobs S, Kull F Jr, Cullitta F, Mulshine JL, Moody TW. (1996) Monoclonal antibody alpha IR-3 inhibits non-small cell lung cancer growth in vitro and in vivo. J. Cell Biochem. 24(suppl): 269-275.

42. Jaques G, Kiefer P, Rotsch M, et al. (1989) Production of insulin-like growth factor binding proteins by small cell lung cancer cell lines. Exp. Cell Res. 184: 396- 399.

43. Pavelić K, Čabrijan T, Hraščan R, et al. (1998) Molecular pathology of hemangiopericytomas accompanied by severe hypoglycemia: oncogenes, tumor-suppressor genes and the insulin-like growth factor family. J. Cancer Res. Clin. Oncol. 124: 307-314. 